\title{
Adrenal Cancer pT4 TNM Finding v7
}

National Cancer Institute

\section{Source}

National Cancer Institute. Adrenal Cancer pT 4 TNM Finding v7. NCI Thesaurus. Code C89404.

Adrenal cancer with tumor of any size, with invasion of adjacent organs. Adjacent organs include kidney, diaphragm, great vessels, pancreas, spleen, and liver. (from AJCC 7th Ed.) 